\title{
EMOCJE I PRACA EMOCJONALNA PERSONELU INSTYTUCJI KOREKCYJNYCH DLA MLODZIEŻY W KONTEKŚCIE DZIAŁAŃ RESOCJALIZACYJNYCH ${ }^{1}$
}

\section{Streszczenie}

Artykuł przybliża problem występowania zarówno emocji, jak i szeroko pojętej pracy emocjonalnej wśród personelu zakładów poprawczych (ZP) oraz schronisk dla nieletnich $(\mathrm{SdN})$ w odniesieniu do skuteczności resocjalizacji w warunkach częściowej izolacji. Autor podjął próbę zastosowania konceptu pracy emocjonalnej do opisu i wyjaśnienia oddziaływań wychowawczych obecnych w instytucjach korekcyjnych dla młodzieży. Broniona jest teza, że u podstaw efektywnych działań resocjalizacyjnych leżą emocje oraz praca emocjonalna, której dokonuje personel $\mathrm{w}$ relacjach $\mathrm{z}$ podopiecznymi. Dyskusji poddane są działania pracowników placówek ukierunkowane na wypracowanie własnych sposobów radzenia sobie z emocjami negatywnymi. W artykule poruszony jest zarówno problem pracy płytkiej, jak i głębokiej oraz ich wpływu na interakcje z wychowankami.

Zaprezentowane w artykule wnioski opierają się na ośmioletnich badaniach jakościowych prowadzonych w ośrodkach resocjalizacyjnych wszystkich typów w całej Polsce. Do analizy zebranych materiałów empirycznych wykorzystany został paradygmat interpretatywny, który daje możliwość uchwycenia interakcyjnego charakteru powstawania emocji negatywnych i pracy emocjonalnej.

* Prof. nadzw. UŁ, Instytut Socjologii, Katedra Socjologii Organizacji i Zarządzania; e-mail: chomczynski@gmail.com

1 Pragnę wyrazić wdzięczność anonimowym recenzentom oraz członkom Redakcji „Przeglądu Socjologicznego" za wartościowe uwagi i konstruktywną krytykę, choć oczywiście osoby te nie ponoszą odpowiedzialności za wszelkie niedoskonałości tekstu. 
Słowa kluczowe: praca emocjonalna, zakłady poprawcze, schroniska dla nieletnich, instytucje totalne, paradygmat interpretatywny, interakcje, resocjalizacja

\section{WSTĘP}

Badania podjęte przez Arlie Hochschild w latach 70. związane z ludzką emocjonalnością dały asumpt do rozwinięcia problematyki emocji na gruncie socjologii, w szczególności zaś socjologii interpretatywnej. Hochschild [2009] na podstawie badań wśród przedstawicieli zawodów usługowych ukonstytuowała wykorzystywane w tym artykule pojęcie pracy emocjonalnej, choć należy podkreślić, że po raz pierwszy terminu ,praca nad emocjami” (sentimental work) użyli Shizuko Fagerhaugh i Anselm Strauss w badaniach nad pracą personelu medycznego podejmowana wobec chronicznie chorych pacjentów. Fagerhaugh i Strauss [1977; także Strauss, Fagerhaugh i zespół 1982] pracę nad emocjami odnosili do pracy nad emocjami pacjenta towarzyszącej stopniowemu wtajemniczaniu go w okoliczności jego choroby i trajektorii z nią związanej. W przypadku niniejszej problematyki bardziej adekwatna do interpretacji rezultatów badań wydaje się mniej deterministyczna koncepcja pracy emocjonalnej Hochschild. Stworzone przez badaczkę konstrukty teoretyczne - pracy płytkiej i głębokiej, pozwoliły opisać procesy dostosowawcze $\mathrm{w}$ zakresie regulacji emocji przedstawicieli zawodów doświadczających intensywnych kontaktów z innymi ludźmi (klientami), które wymagają od nich ukrywania i modyfikacji odczuwanych emocji. Aktywność pracowników w zakresie regulacji doświadczanych emocji jest skierowana do wewnątrz i wiąże się z intensywną pracą nad emocjami, zwaną ,pracą emocjonalną", której efektem jest działanie wobec innych, jednak pozbawione takiego ładunku emocjonalnego jak przed podjęciem pracy nad nimi. W moim przekonaniu koncepcję pracy emocjonalnej można z powodzeniem odnieść do działań personelu instytucji korekcyjnych. Praca z wychowankami z reguły obarczona jest licznymi trudnościami, które rodzą emocje negatywne zarówno u nich samych, jak i po stronie personelu. Każda ze stron na swój sposób wypracowuje strategie radzenia sobie z nimi, także w efekcie wzajemnego wpływu. W niniejszym artykule chciałbym jednak skupić się w największym stopniu tylko na jednej ze stron, mianowicie pracownikach, choć tam, gdzie to konieczne dla klarowności wywodu, staram się oddać również perspektywę podopiecznych. Przyjmuję, że emocje towarzyszące oddziaływaniom resocjalizacyjnym mają charakter kluczowy, gdyż wpływają na skuteczność samej resocjalizacji. Kierując 
się $\mathrm{w}$ artykule tą tezą, chcę dokonać opisu uwarunkowań powstawania emocji po stronie personelu, sposobów radzenia sobie z nimi i procesów związanych z dynamiką przeżywanych emocji.

\section{CZYM SĄ EMOCJE?²}

Problem emocji i kontekstów ich powstawania od samego początku wiązał się z psychologią. Janusz Reykowski [1992: 57] definiuje emocję jako „każdy stan wzburzenia albo podniecenia psychicznego, proces regulacji uruchamiany, gdy człowiek styka się z bodźcami (zewnętrznymi lub wewnętrznymi) mającymi znaczenie dla jego organizmu lub jego osobowości”. Problematyka emocji obejmuje zatem tak mechanizmy ich wzbudzania, jak i regulacji. W literaturze przedmiotu wyróżniamy emocje podstawowe (pierwotne) i pochodne [Fehr, Russel 1984; Shaver, Schwartz i in. 1987]. Emocje pierwotne to stany idealne, o których wnioskuje się bezpośrednio [Plutchik 1980]. Możliwość ich bezpośredniej obserwacji, na co wskazuje Robert Plutchik, pozwala skoncentrować uwagę na zachowaniach emocjonalnych aktorów społecznych i kontekstach, w jakich one występują. Emocje podstawowe stanowią bazę (prototyp) dla powstania innych, bardziej złożonych stanów emocjonalnych, które także są przedmiotem niniejszych rozważań (np. emocja dumy). Emocje pochodne powstają wskutek pojawienia się emocji podstawowych w specyficznych sytuacjach społecznych [Kemper 1987]; są to na przykład poczucie winy, wstyd, nadzieja, duma.

Problematykę emocji warto powiązać z procesami ich ujawniania lub hamowania z perspektywy psychologicznej. Istotny jest tutaj proces regulacji emocji, czyli ,proces inicjujący, modulujący i podtrzymujący doświadczanie emocji oraz operacje poznawcze i zachowania z tym doświadczeniem związane" [Doliński 2004: 381]. Z procesem regulacji emocji wiąże się proces samokontroli emocjonalnej, czyli przejawianie zachowania zgodnego z przyjętymi standardami społecznymi. W wyniku procesu samokontroli może nie dojść do ekspresji przeżywanych emocji, jak również do zablokowania działań związanych z przeżywaniem emocji, na przykład powstrzymywania się od zachowań skrajnie agresywnych, nawet w wypadku odczuwania silnej złości [Doliński 2004: 389]. W przypadku intensywnych emocji negatywnych doświadczanych przez pracowników ZP i SdN istnieje silna presja, tak instytucjonalna, jak koleżeńska, by kontrolować ekspresję emocjonalną i jej wpływ na własne procesy emocjonalne [Kofta 1979: 24; por. Reykowski 1992: 48-50].

2 Wątek emocji, ale w odniesieniu do nauczycieli ze szkół działających przy zakładach poprawczych i schroniskach dla nieletnich oraz szkół „zwykłych” został opisany w artykule: [Pawłowska, Chomczyński 2012: 212-235]. 
Należy pamiętać, że jesteśmy w stanie oceniać jedynie ekspresję emocji, czyli „wszelkie sygnały emitowane przez jednostkę, będące dla kogoś innego wskazówką przeżywania przez tę osobę określonej emocji”" [Doliński 2004: 351]. Poczynione w artykule konstatacje bazują na ekspresji emocjonalnej, na podstawie której wnioskuje się o przeżywanych emocjach, jak również na wypowiedziach badanych osób.

\section{ZAGADNIENIE EMOCJI W PODEJŚCIU INTERPRETATYWNYM ${ }^{3}$}

Emocjonalny aspekt działań zbiorowości ludzkich stał się domeną zainteresowań socjologów dość późno, bo pod koniec lat siedemdziesiątych ubiegłego stulecia [zob. Shott 1979: 1317; Denzin 1983: 402], choć już w pracach Emila Durkheima [1990: 383] znaleźć można wątek roli emocji w uczestnictwie jednostki w życiu społecznym.

Szukając korzeni zainteresowań emocjonalnością człowieka w ramach nurtu socjologii interpretatywnej, oprzeć się można na Cooleyowskiej koncepcji jaźni, której procesom towarzyszą emocje w postaci uczuć żywionych wobec siebie samego [por Mucha 1992: 181]. Charles Cooley emocjom przypisuje pewną energię leżącą u podstaw interakcji społecznych, w które angażuje się jednostka [por. Konecki 2005: 173]. Warto zauważyć, że Cooley [1922: 184-185] w głównej mierze skoncentrował się na dyskutowanych w niniejszym artykule emocjach dumy i wstydu, łącząc je z koncepcją jaźni odzwierciedlonej [por. Scheff 2003; Konecki 2005: 173-174].

Thomas Scheff, przyjmując założenia Cooleya, uczynił z emocji dumy i wstydu kluczowe emocje społeczne [Scheff 2003], które decydują o procesie socjalizacji. Emocje te, poprzez mechanizmy składające się na jaźń odzwierciedlona, „sterują" postępowaniem człowieka zgodnie z oczekiwaniami innych. To właśnie dzięki pracy nad okazywaniem emocji przy wykorzystaniu procesów jaźni odzwierciedlonej personel ZP i SdN próbuje osiagać efekty resocjalizacyjne. Należy jednak pamiętać, że praca ta jest nadzorowana i wykonywana przez personel instytucji korekcyjnych, od którego dyspozycji i kompetencji emocjonalnych zależy powodzenie procesu resocjalizacji.

Fragment opisujący perspektywę teoretyczną i metodologiczną jest w części zbieżny $\mathrm{z}$ treścią mojego artykułu opublikowanego w „Polish Sociological Review” (Emotion work in the context of the resocialization of youth in correctional facilities in Poland) traktującego o pracy emocjonalnej wychowanków. Zbieżność jest konsekwencją przyjęcia określonej perspektywy teoretycznej i metodologicznej w ramach prowadzonego projektu. Część wynikowa, będąca zasadniczą częścią artykułu, stanowi odrębną całość. 
Erving Goffman także analizował emocje w działaniach społecznych, koncentrując się na perspektywie bezpośrednich kontaktów jednostki z innymi [zob. Collins 2004: 16-17]. Goffman wskazuje na instrumentalnie inicjowane techniki zachowań, jakimi ludzie posługują się w celu wywołania u siebie lub/i innych określonych afektów [por. Pawłowska 2013: 57-59; Hochschild 1979: 556]. Przykładem opisywanych przez Goffmana emocji mogą być wstyd i zakłopotanie powstające, ,kiedy projektowana przez jednostkę jaźń jest zagrożona podczas interakcji" [tł. własne, Goffman 2008: 114; zob. Kemper 2011: 136], a także emocje pojawiające się w przypadku utraty twarzy [Goffman 2000].

Dalszy rozwój koncepcji emocji w obrębie nurtu interakcjonistycznego jest zasługą Susan Shott, która opracowała jedną z pierwszych zwartych koncepcji, nawiązując wprost do szkoły chicagowskiej [por. Turner 2004: 497; patrz także Shott 1979: 1320-1321]. Doświadczanie emocji badaczka postrzega z perspektywy symbolicznego interakcjonizmu, wskazując na zdolność jednostek do reagowania na siebie jako obiekty, co oznacza, że poprzez przyjmowanie roli uogólnionego innego stają się one przedmiotem własnych działań. Ustalenia Susan Shott są istotne dla zrozumienia problematyki radzenia sobie z doświadczanymi przez siebie emocjami i pracą emocjonalną stanowiącą temat niniejszego artykułu.

W interpretatywnej analizie emocji można oprzeć się także na teorii rytuałów interakcyjnych Randalla Collinsa, inspirowanej przemyśleniami Goffmana, a także Durkheima. Collins [1993: 206; 2004: 33] operował na poziomie małych grup, analizując ,łańcuchy interakcji” (chain interactions) oraz czynniki je kształtujące i intensyfikujące, wskazując, że źródeł silnych emocji należy doszukiwać się w osłabieniu lub utracie przynależności jednostki do grupy [por. Simmel 1955].

Wątek ludzkiej emocjonalności, z perspektywy społeczno-interakcyjnej, poruszał także jeden z pionierów socjologii emocji, a również bliski współpracownik Randalla Collinsa, Theodore Kemper. Akcentował on fakt, że istnieją cztery podstawowe emocje, mianowicie strach, złość, depresja (przygnębienie) i satysfakcja, na bazie których, w toku socjalizacji, zaszczepiane są emocje pochodne [Kemper 1987: 26]. Randall wraz z Collinsem stali na stanowisku, że występowanie emocji podstawowych wiąże się z relacjami władzy, powiązanymi ze wszystkimi relacjami społecznymi.

Interesująca w tym kontekście wydaje się także koncepcja Thomasa Scheffa. Wzorując się na pracach czołowych przedstawicieli podejścia interpretatywnego, m.in. Deweya, Cooleya, Meada i Goffmana, a także Freuda czy Durkheima, Scheff [2003; 2006] z pojęcia wstydu i dumy uczynił główną oś rozważań. W swoich przekonaniach bliski był twierdzeniom Norberta Eliasa [2011: 550-552], zaznaczając, że „duma daje sygnał w kierunku solidarności, zaś wstyd wobec alienacji” 
[Scheff 1997, bez tytułu]. Interakcyjnych uwarunkowań źródeł wstydu upatrywał w Cooleyowskiej koncepcji jaźni odzwierciedlonej, przedstawionej w Human Nature and the Social Order [por. Scheff 2006: 53].

Przyjmując problem pracy emocjonalnej jako zjawiska priorytetowego w procesie resocjalizacji nieletnich, warto, choć w kilku zdaniach, odnieść się do kwestii radzenia sobie z emocjami negatywnymi z perspektywy interpretatywnej.

\section{STRATEGIE RADZENIA SOBIE Z EMOCJAMI NEGATYWNYMI Z PERSPEKTYWY INTERPRETATYWNEJ}

W pojęcie pracy emocjonalnej wpisane jest podjęcie przez podmiot działań na rzecz radzenia sobie z emocjami, zwłaszcza tymi negatywnymi. Istotne wydają się przemyślenia Goffmana zawarte w książce Instytucje totalne (Asylums), w której opisano realia typowe dla organizacji zamkniętych. Choć Goffman [2011: 182] koncentruje się głównie na strategiach i emocjach doświadczanych przez podopiecznych szpitala psychiatrycznego, to wnioski, do jakich dochodzi, wskazuja na konsekwencje emocjonalne wynikające z izolacji, a także intensywności relacji międzyludzkich w warunkach instytucji totalnej.

Powracając do przemyśleń Susan Shott, należy podkreślić, że umiejscawiała ona samo przeżywanie emocji na gruncie socjalizacyjnym, w ramach którego jednostka definiuje swoje emocje z perspektywy norm kultury, do której przynależy [Shott 1979: 1319]. W myśl założeń symbolicznego interakcjonizmu jednostka ludzka w toku interakcji tworzy określone definicje sytuacji poprzez symboliczną interpretację otaczającej ją rzeczywistości. W ten sposób krystalizacji ulega linia działania (line of action) podmiotu [por. Blumer 1969: 66-67], przez Koftę [1979] częściowo utożsamiana ze strategiami emocjonalnymi. Te ostatnie z kolei, w przekonaniu Shott [1979: 1323-24], wiążą się z pojęciem kontroli społecznej, której warunkiem jest przyjmowanie przez podmiot roli „innego”. Empatia, powstająca na skutek zyskania perspektywy innego, warunkuje prace emocjonalną [por. Turner, Stets 2009: 127].

Koncepcja pracy emocjonalnej kojarzona jest $\mathrm{z}$ utrzymaną w duchu dramaturgicznym koncepcją emocji Arlie Hochschild, jak również sposobami zarządzania emocjami. Posiłkując się badaniami prowadzonymi w środowisku pracy [por. Szczygieł i zespół 2009: 156], bazuje ona na pojęciu kultury emocji. Składają się na nie „zespoły wyobrażeń na temat tego, co powinni czuć ludzie w różnego rodzaju sytuacjach" [Turner, Stets 2009: 51]. Hochschild [1979: 551; thum. własne] stwierdziła, że „emocje mogą być i są obiektem działań zarządczych”. Jest to ważny wątek, ze względu na zaobserwowane przez nią działania personelu 
ukierunkowane na ujarzmienie negatywnych emocji, zarówno własnych, jak i wychowanków. W tym kontekście interesujące wydaje się także uformowane przez badaczkę pojęcie pracy emocjonalnej ${ }^{4}$ (emotional work), które odnosi się do próby zmiany emocji lub uczucia w zakresie stopnia i jakości ich odczuwania ${ }^{5}$ [por. Hochschild 1979: 561]. Wykorzystując przemyślenia Freuda i Goffmana [por. Brook, Koch, Wittel 2013: 276], Hochschild zaakcentowała wysiłek włożony w zmianę, nie zaś jej rezultat, wskazując na takie pojęcia, jak: kontrola nad emocją (emotion control) i zarządzanie emocją (emotion management), które zakładają aktywną próbę zmiany istniejącego stanu emocjonalnego [Hochschild 2009: 238]. Przydatny wydaje się także, zaproponowany przez Hochschild, podział na działanie powierzchowne i głębokie. W ramach pierwszego rodzaju działania ,narzędziem pracy jest w tym wypadku ciało, a nie dusza" [Hochschild 2009: 41], gdyż działanie powierzchowne opiera się jedynie na gestach behawioralnych, z racji faktu, że „emocje pozostają niezmienione” [Szczygieł i zespół 2009: 157]. Ciału przypisuje ona rolę narzędzia służącego ekspresji emocjonalnej [Hochschild 2009: 42]. Wątek ciała jest także bardzo istotny w przypadku niniejszych badań. Wychowankowie w ramach działania powierzchownego dokonują świadomego przeobrażania wyglądu fizycznego. Poprzez tatuowanie, okaleczanie ciała i inne komunikaty „cielesne” starają się sprowokować nie tylko określone emocje u wychowawców, lecz także inicjują je u siebie. W przypadku personelu działanie głębokie polega na intencjonalnym wzbudzaniu w sobie określonej emocji pozytywnej (np. dumy) w miejsce negatywnej (np. złość). W rezultacie przestrzeń pomiędzy zachowaniem i ekspresją emocjonalną staje się tym mniej widoczna, im bardziej skuteczna jest praca emocjonalna [por. Zapf 2002: 242-243; Kim i Han 2009: 229].

\section{KONCEPCJA PRACY EMOCJONALNEJ W REALIACH INSTYTUCJI KOREKCYJNYCH DLA MŁODZIEŻY}

Próba wykorzystania koncepcji pracy emocjonalnej Arlie Hochschild do analizy instytucji zamkniętej, której przykłady stanowią ZP i SdN, wymaga wyjaśnienia. W przypadku niniejszego artykułu stosuję nieco odmienną perspektywę pracy emocjonalnej (emotional work), w rozumieniu, jakie nadała mu Hochschild,

\footnotetext{
4 Należy oczywiście podkreślić, że całościowa koncepcja pracy emocjonalnej nie może być zastosowana w przypadku badanych tutaj instytucji, w których interakcje pomiędzy stronami mają zupełnie różny charakter i którym towarzyszą odmienne intencje wobec wolnorynkowych relacji pracowników i klientów.

5 Gruntowny przegląd literatury w zakresie pracy emocjonanej znaleźć można w artykule: [Zapf 2002].
} 
wywodząca swą koncepcję z obserwacji przedstawicieli zawodów usługowych, którzy zorientowani byli na regulowanie emocji w kontaktach z klientami. Celem niniejszego artykułu jest zwrócenie uwagi na problem emocji doświadczanych przez personel instytucji korekcyjnych w pracy resocjalizacyjnej i sposoby radzenia sobie z nimi. W szczególności poruszony jest problem działań związanych $\mathrm{z}$ pracą emocjonalną wykonywaną przez pracowników w relacjach z podopiecznymi w kontekście szkolno-wychowawczym [Price 2001: 162; por. także, Kerr, Brown 2016; Pawłowska 2013].

Przyjmując argumentację Heather Price [2001] o możliwości wykorzystania koncepcji pracy emocjonalnej $\mathrm{w}$ badaniach relacji wychowawczych, próbuje wykazać związek pomiędzy pracą emocjonalną (płytką i głęboką) a oddziaływaniami pedagogicznymi, jakim poddana jest młodzież w środowisku instytucji korekcyjnych. Stoję na stanowisku, że koncepcja pracy emocjonalnej pozwala wyjaśnić rolę emocji w procesie resocjalizacji.

\section{METODOLOGIA BADAŃ}

\section{Założenia metodologiczne}

Przyjęta metodologia badań powinna respektować złożoność otaczającej nas rzeczywistości i specyfikę danych, które chcemy uzyskać wraz z kontekstem prowadzonych badań [Blumer 1969: 22-23; Goffman 2011: 8]. Perspektywa dramaturgiczna Goffmana, wpisana w paradygmat socjologii interpretatywnej [Turner 2004: 456], pozwala spojrzeć na codzienną naturę interakcji z postulowanej przez Georga Simmla ,żabiej perspektywy” [Simmel 1955; zob. także Piotrowski 1985]. Jest to sposób patrzenia na zjawiska społeczne ,z dołu”, tam, gdzie one faktycznie zachodza, w ramach społecznie konstruowanej rzeczywistości leżącej u podstaw ładu społecznego [por. Czyżewski 2013: 14]. W tym przypadku ład organizacyjny kreowany jest przez interakcje wychowanków zakładów poprawczych ukierunkowanych na siebie wzajemnie, ale i na kadrę. W badaniach instytucji totalnych należy założyć, że niejako same „chronią” one swoje tajemnice [Moczydłowski 2002]. Kluczowym problemem w opisywaniu zjawisk w nich zachodzących jest niechęć badanych do eksponowania swoich „rzeczywistych” poglądów i motywów działań.

\section{Techniki badawcze}

Biorąc pod uwagę przedstawione wyżej założenia i specyfikę terenu, najbardziej odpowiednie wydają się techniki zapewniające jak najdłuższy kontakt badacza 
z badanymi, czego rezultatem jest większe zaufanie, stwarzające niekiedy możliwość „przedarcia się” przez deklarowaną warstwę wypowiedzi, typową dla technik opartych na krótkotrwałym kontakcie [Konecki 2000]. Ta konstatacja przesądziła o wykorzystaniu obserwacji uczestniczącej jawnej oraz wywiadu swobodnego. Oba te narzędzia dają badaczowi możliwość śledzenia przez dłuższy czas interakcji w badanym środowisku, jak również pozwalają na wykrycie przynajmniej niektórych uwarunkowań faktycznie leżących u podstaw działań indywidualnych i zbiorowych [Hammersley, Atkinson 2000: 16-17]. W badaniach wykorzystano także analizę dokumentów (karty obserwacji, regulaminy wewnętrzne, opisy wydarzeń nadzwyczajnych, opinie działu diagnostycznego/ diagnostyczno-korekcyjnego o stopniu demoralizacji itd.) oraz analizę wizualną opartą na materiale filmowym z kamer zainstalowanych w badanych instytucjach. Analiza wizualna była przeprowadzana przy udziale personelu placówek, który wyjaśniał badaczowi naturę interakcji i działań podejmowanych przez wychowanków, a także umożliwił konsultowanie na bieżąco wniosków dotyczących wizualnych przejawów socjometrii grupowej. Działania te dały możliwość odczytania natury gestów werbalnych i niewerbalnych ujawnianych przez podopiecznych, przełożyły się na większą wrażliwość przy dokonywaniu obserwacji oraz interpretowaniu i definiowaniu interakcji dostrzeganych u wychowanków.

\section{Materiał badawczy i charakterystyka badanej próby}

Badania zostały zrealizowane w latach 2008-2015 i opierają się na wywiadach swobodnych $^{6}$ przeprowadzonych wśród personelu żeńskich i męskich ZP i SdN (52 wywiady) oraz wychowanek (12) i wychowanków (30). Ze względu na kluczową rolę zaufania wywiad był niejednokrotnie ponawiany z tymi samymi osobami, co pozwoliło nie tylko uzyskać nowe dane, lecz także zweryfikować wcześniejsze. Łącznie spędziłem w ,terenie” 7 miesięcy, stosując technikę obserwacji uczestniczącej jawnej. W tym okresie, nocując w tych instytucjach, starałem się uczestniczyć we wszystkich aktywnościach podopiecznych: przebywałem w szkole w czasie nauki zawodu w ramach warsztatów, w trakcie spożywania posiłków na stołówce, jak również w internacie w czasie wolnym od zajęć dydaktycznych. Ponadto analizie poddane zostały udostępnione przez

6 Po transkrypcji wywiadów uzyskano prawie 1000 stron materiału empirycznego wzbogaconego ponad 100-stronicowym zapisem z obserwacji uczestniczącej jawnej. Materiał ten w dalszej części podlegał kodowaniu otwartemu, selekcyjnemu i rzeczowemu w programie ATLAS TI służącym do analizy danych jakościowych. 
personel akta wychowanków (26 dokumentów) oraz 182 opinie skierowane do sądów rodzinnych.

Celem niniejszego artykułu jest próba wykazania związku pomiędzy pracą emocjonalną personelu instytucji korekcyjnych na poziomie płytkim i głębokim a skutecznością oddziaływań resocjalizacyjnych. Na podstawie zebranych danych przyjęto następujące hipotezy badawcze:

- personel placówek doświadcza silnych emocji negatywnych w relacji $\mathrm{z}$ wychowankami, więc wypracowuje instytucjonalnie akceptowalne strategie radzenia sobie z nimi;

- personel doświadcza emocji negatywnych w sytuacjach definiowanych przezeń jako zagrożenie dla jego władzy i statusu zgodnie z koncepcją Randalla Collinsa i Theodore'a Kempera;

- źródłem emocji negatywnych wśród personelu są uwarunkowania instytucjonalne;

- źródłem emocji pozytywnych wśród personelu jest duma wnikająca z odczuwanej satysfakcji ze współpracy z wychowankami. Emocje pozytywne stanowią czynnik motywacyjny w sytuacjach doświadczania emocji negatywnych;

- pozytywne emocje personelu w relacjach z wychowankami prowadzą do stworzenia więzi emocjonalnej warunkującej skuteczną resocjalizację;

- pozytywne emocje doświadczane przez personel motywują go do radzenia sobie $\mathrm{z}$ emocjami negatywnymi w ramach pracy emocjonalnej;

- świadomość własnych emocji i kontekstów ich występowania wśród personelu stanowi klucz do podjęcia pracy emocjonalnej;

- przejście od płytkiej do głębokiej pracy emocjonalnej wpływa na skuteczność oddziaływań resocjalizacyjnych.

\section{UWARUNKOWANIA POWSTAWANIA EMOCJI WŚRÓD PERSONELU}

Instytucje korekcyjne dla młodzieży obfitują w okoliczności, które prowokują do powstawania emocji i ich ekspresji zarówno w przypadku personelu, jak i wychowanków. To jednak personel zobowiązany jest wyznaczać obowiązujące standardy zachowań emocjonalnych. Warto zatem dokonać analizy mechanizmów wpływających na pobudzenie emocjonalne oraz na sposoby jego rozładowania. 


\section{Emocje negatywne a praca $\mathrm{z}$ wychowankami}

Bezpośredni kontakt z wychowankami stanowi dla personelu źródło emocji tak pozytywnych, jak i negatywnych. Im bardziej jest on intensywny, tym w większym stopniu prowokuje powstawanie emocji. W kontekście relacji personelu z wychowankami jako źródłem emocji negatywnych emocje można podzielić na wywołane: postępowaniem podopiecznych wobec personelu, procesami empatycznymi oraz bezpośrednią bliskością.

\section{Emocje powstałe w wyniku zachowania wychowanków}

Emocje powstałe w wyniku określonego zachowania podopiecznych w przeważającej części odbierane są przez kadrę jako atak na sferę ja - godność, szacunek, respekt - lub też postawienie personelu w sytuacji, kiedy musi okazać strach w obecności podopiecznych.

Rozmówca: Wiadomo, że na początku [ci, co brali udział w buncie] to nie mieli co liczyć na pomoc od wychowawców, bo wychowawcy mówili co ty chciałeś spalić mojego kolege $i$ ty chcesz ode mnie jaką́s pomoc... [wychowanek, ZP].

Gdy pracownicy definiują sytuację w kategoriach umniejszenia własnego ja, zwłaszcza w sytuacji publicznej, nabierają przekonania, że stracili twarz [Goffman 2000], co przekłada się na intensyfikację emocji, szczególnie w przypadku braku doświadczenia w wypracowywaniu strategii pozwalającej na jej neutralizację.

R: Taki wychowanek może cię urazić i aż ci w pięty pójdzie, może ci grozić i się go po prostu boisz. Może powoływać się na znajomości mafijne i masz strach o siebie i rodzinę [wychowawca, ZP].

Najsilniejszych emocji negatywnych doświadcza personel w przypadku udanych prób samobójczych wychowanków lub ich działań ukierunkowanych na utratę zdrowia. Sytuacjom takim towarzyszy emocja winy i bezradności. Powstałe emocje zazwyczaj nie podlegają pełnemu ,zagospodarowaniu” i personel nie potrafi sobie z nimi poradzić. Są one wciąż żywe i przy różnych okazjach dochodzą do głosu we wspomnieniach.

Pamiętam jak mi się chłopak targnął na życie to trzy dni z domu nie wychodziłem. Nie mogłem tego przeżyć, że nie udało mi się go uratować... [wychowawca, ZP].

Niektóre emocje negatywne (złość) biorą się z niemożności wpłynięcia na jakość interakcji z wychowankiem. W jej wyniku pojawia się dyskomfort, którego nie można zlikwidować, gdyż znajduje się poza kontrolą sytuacji. Dla personelu przywiązującego dużą wagę do kontroli kontekstu interakcyjnego jest to źródłem emocji złości i frustracji z nią związanej. 
R: Wychowanek ma bardzo ubogie słownictwo i wiedzę - zniechęcenie, brak motywacji - nie bądź drobiazgowy a chłopak pyta czy go obrażam - wkurzasz się bo nie wiesz jak reagować. Pytam na przykład używając słowa „konwersacja” i tylko jeden chłopak zrozumiał w ciagu 20 lat. Czasami masz dość [wychowawca, SdN].

\section{Emocje związane z procesami empatycznymi}

Emocje negatywne, które powstają na skutek procesów empatycznych, są z reguły bardzo silne i utrzymują się dość długo. Dzieje się tak dlatego, że najczęściej wynikają one z pogwałcenia przez podopiecznych podstawowych norm i zasad współżycia społecznego zinternalizowanych przez personel. Są one konsekwencją urazu dokonanego na systemie aksjonormatywnym, który odpowiada za poczucie bezpieczeństwa, przewidywalności zdarzeń i dokonywanie ich racjonalizacji w zgodzie z wyznawanymi wartościami. Brak możliwości dokonania racjonalizacji popełnionych przez wychowanków czynów podtrzymuje ciągłość odczuwanych emocji w czasie.

Czuję gniew i obrzydzenie z racji przestępstwa, nawet teraz - gwałciciel dzieci - znasz jego historię, czytałeś akta, szczegółowo, masz to wszystko przed oczami, sam masz dzieci. Albo chłopiec który 22 letniej kobiecie wydłubał oczy po tym jak ją zgwałcił, po to żeby nie mogła zeznawać [kierownik internatu, SdN].

Z reguły procesy empatyczne współtworzą matrycę spostrzeżeniową odnoszoną do danego wychowanka, poprzez którą dochodzi do jego percepcji, niejako w oddzieleniu od jego bieżącego zachowania. W takich przypadkach emocje negatywne uruchamiane są za pomocą wyobraźni bez faktycznej bezpośredniej relacji z ich obiektem. Sam doświadczyłem tego rodzaju emocji wobec chłopca, z którym, po tym jak grałem z nim w tenisa stołowego, dowiedziałem się, że przebywając w domu dziecka, dokonywał gwałtów na dwu- i trzyletnich dzieciach. Choć kontynuowałem zabawę, to jednak jego wizerunek, wykonywane gesty, spojrzenia uległy w mojej świadomości gruntownej przemianie, także te zaprzeszłe. $Z$ autopsji mogę stwierdzić, że czułem silne emocje negatywne, takie jak złość, nienawiść, wstręt, z którymi nie potrafiłem sobie poradzić.

\section{Emocje wynikające z bezpośredniej bliskości}

Zebrane dane empiryczne, w tym również wyniki obserwacji uczestniczącej jawnej, wskazuja, że źródłem emocji negatywnych, choć nie tak silnych jak w poprzednim kontekście, może być bezpośrednia bliskość wychowanka, gdy wiąże się ona z pejoratywnym oddziaływaniem na zmysły. 
Gniew - związany z tym ze nie radzisz sobie z emocjami wstrętu wobec wyglądu chłopca - np. chłopiec z łuszczyca, chory i brzydko pachniał, ci co się nie myją, musisz ich uczyć higieny - pranie bielizny, mycie nóg, same podstawy [wychowawca, ZP].

Tego rodzaju sytuacje rodzą emocje wstrętu oraz związanego z nimi gniewu. Ich źródło sięga poczucia obrazy i braku respektu w aspekcie ekspozycji na niezawinioną sytuację silnego dyskomfortu. Wychowanek, który nie dba o higienę, jest obwiniany także o brak dbałości o innych, narażonych na konsekwencje wynikające z jego fizycznej obecności. W sposób naturalny buduje się solidarność personelu z pozostałymi wychowankami, która przekłada się na kolektywnie konstruowaną definicję sytuacji i jej głównego aktora, który, posługując się terminologią Goffmana [1961/2011], podlega napiętnowaniu jako osoba zdyskredytowana.

\section{Zagrożenie władzy i statusu jako źródło emocji negatywnych}

Wspomniane wcześniej emocje wynikające z zachowania wychowanków, którego konsekwencjąjest odczuwany przez personel atak na własne ja, można powiązać z omówioną wcześniej koncepcją Randalla Collinsa i Theodore'a Kempera dotyczącą emocjonalnej reakcji na zagrożenie władzy i statusu. Dla personelu źródłem koncepcji siebie i swojej roli w instytucji korekcyjnej jest władza i status, które z nią korespondują $\mathrm{i}$ ją wspomagają. Z nich wynika określony styl komunikacyjny przekładający się na interakcję o charakterze asymetrycznym. Gdy dochodzi do jej gwałtownego zaburzenia na skutek wypowiedzi lub też działań inicjowanych podopiecznych, na moment zachwianiu ulega poczucie władzy i związanego z nią statusu, czego konsekwencją są emocje złości, gniewu, a czasami strachu, który je wzmaga.

Ten wychowanek, który stoi przede mną, krzyczy do mnie ty kurwo, ty frajerze, ty ktoś tam, on to robi dlatego, że tak, myśli, czy dlatego, że musi tak zrobić w tym momencie akurat tak [...] każdy jest tylko człowiekiem i też jakby mamy emocje i oni też mówię czasami potrafią nas wyprowadzić z równowagi (wychowawca, ZP).

Jak ci taki gówniarz [...] pyskuje to aż cię niekiedy krew zalewa [wychowawca, ZP].

Władza i status są postrzegane jako źródło ładu i porządku, które leżą u podstaw bezpieczeństwa [Chomczyński 2013], więc atak na nie nabiera cech bardziej ogólnych, które pozwalają usprawiedliwić nie tylko emocje negatywne, lecz także ostrzejsze sposoby ich rozładowywania. 


\section{Źródłem emocji negatywnych są uwarunkowania instytucjonalne}

Choć personel doświadcza emocji przeważnie w relacjach z podopiecznymi, to należy mieć na uwadze fakt, że część $\mathrm{z}$ nich wiąże się ze specyfiką pracy w ZP i SdN. Mają one jednak przełożenie na relacje z wychowankami i także podlegają wypracowywaniu strategii radzenia sobie z nimi. Pracownicy niekiedy wymieniali typ zakładu jako czynnik, który wiąże się z powstawaniem emocji negatywnych.

Jest jeden wychowawca, to jest zakład półotwarty, czyli jest to zakład taki, gdzie chłopacy się poruszają cały czas po grupie, jeżeli chcą przejść do innej grupy muszą się zapytać drugiego wychowawcy, czy mogą wyjść i to kiedyś tam powiedział taki generał więziennictwa [...] że najgorszy zakład, to są otwarte i półotwarte, tam się ludzie najbardziej wypalają zawodowo. Zmęczeni są psychicznie, bo teraz ja siedzę, robię jakieś papiery, które muszę zrobić, a tu mi wchodzi chłopak Panie Wychowawco da mi Pan skarpetki? Ja mówię poczekaj coś napiszę, wchodzi następny Panie Wychowawco skończyła mi się pasta do zębów, Panie Wychowawco ja mam problem, bo moja mama coś tam [...]. I tak jest non stop....tak jest non stop, więc trzeba po prostu się jakoś do tego.... [wychowawca, ZP].

Uwagi z powyższego opisu znalazły potwierdzenie w moich obserwacjach. Źródłem emocji negatywnych po stronie personelu była z jednej strony bezustanna interakcja z wychowankami, którzy co chwila zjawiali się z różnego rodzaju sprawami (np. brak pasty do zębów, chęć wzięcia papierosa, włączenia telewizora), z drugiej zaś konieczność wykonania rozbudowanej sprawozdawczości. Należy jednak zaznaczyć, że wychowankowie są w dużej mierze ubezwłasnowolnieni przez instytucję, w której się znajdują, a której zasady wymagają od nich pytania o pozwolenie wykonania nawet najdrobniejszej czynności. Paradoks polega na tym, że wychowankowie, zachowując się zgodnie z oczekiwaniami personelu, jednocześnie wywołują u niego negatywne emocje. Mechanizm powstawania emocji jest tu autopojetyczny, gdyż z racji specyfiki instytucji i charakteru pobytu podopiecznych ich wola jest ograniczona. Wychowawca natomiast oprócz nadzoru zobowiązany jest do pracy biurowej, która wymaga skupienia, gdyż ewentualne błędy są surowo karane przez instytucje nadzorujące i kontrolne w trakcie audytu. Perspektywa personelu jest tutaj zdecydowanie inna niż podopiecznego odnośnie do wywoływania negatywnych emocji.

Ważniejsza od typu zakładu (ten argument nabiera cech plemiennych i wymieniany jest zazwyczaj zgodnie przez społeczność danego typu jednostki, wchodząc w skład świadomości zbiorowej) jest jednak specyfika pracy jako taka. Wiele osób zajmujących kierownicze stanowiska skarżyło się na fakt, że ich możliwości personalne wobec osób, które źle świadczą swoją pracę, są ograniczone ze względu na ochronę prawną tych osób (karta nauczyciela). Mimo podejmowanych 
kroków dyscyplinujących ruchy kadrowe należą do rzadkości. Niejednokrotnie pojawiał się argument ,psucia pracy resocjalizacyjnej”.

Emocje to także wypalenie zawodowe i trwanie w pracy ze względu na dobre uposażenie, choć nic się już do niej nie wnosi a nawet się szkodzi. Trudno się pozbyć takiego pracownika [dyrektor szkoły, ZP].

Do innych uwarunkowań należy płaska struktura organizacyjna mająca wpływ na labilność wertykalną zatrudnionych, a także relacje międzyludzkie. Społeczność pracownicza rzadko kiedy jest solidarna wobec siebie, częściej jest podzielona licznymi sporami ideologicznymi, co przekłada się na istnienie koalicji i stronnictw, a także występowanie konfliktów, w które niekiedy angażowani są nawet wychowankowie. Ci ostatni niejednokrotnie starają się uzyskać w podobnych sytuacjach korzyści, co ma wpływ na obniżenie autorytetu personelu [Chomczyński 2013: 112-113].

Tym co frustruje jest brak awansów - duża ilość anonimów, donosów. Częste jest także plotkowanie obgadywanie ocenianie - to w relacji z kolegami [kierownik internatu, ZP].

Istotne jest wzajemne zaufanie ze strony personelu, które przekłada się na poczucie satysfakcji i bezpieczeństwa. Z przeprowadzonych przeze mnie obserwacji wynika, że personel często nie ufa sobie nawzajem, natomiast wychowankowie obdarzają się zaufaniem ${ }^{7}$. W konsekwencji pracownicy doświadczają silnych emocji negatywnych związanych z poczuciem zagrożenia ze strony swoich kolegów. Niekiedy stan takiego napięcia emocjonalnego jest rozładowywany na wychowankach (np. poprzez uszczypliwości, przydzielanie dodatkowych zadań).

\section{Emocja dumy a satysfakcja ze wspólpracy z wychowankami}

Emocja dumy wiąże się z jaźnią odzwierciedloną [Cooley 1922; Scheff 2003; Konecki 2005]. Wychowawcy, którzy zwracali uwagę na dumę, wiązali ją bezpośrednio z sukcesami wychowanków, postrzeganymi jako efekt ich pracy. Dzięki poczuciu dumy nabierali przekonania niejako „na zapas”, że ich praca ma sens nawet wtedy, gdy obecna sytuacja nie napawa optymizmem.

Spotykasz chłopaka po pięciu latach i idzie z żoną i dwojgiem dzieci, to bardzo cieszy. A w zakładzie jeśli np. dobrze napisze test gimnazjalisty, wygra konkurs, powie wiersz że pani się popłacze lub nagra fajną piosenkę i płytę - daje ci to kopa na później (wychowawca, $\mathrm{SdN})$.

7 Na problem braku wzajemnego zaufania wśród personelu ZP w kontekście kapitału społecznego zwrócił mi uwagę Przemysław Frąckowiak w referacie pt. ,Resocjalizatorzy i resocjalizowani wobec normy zaufania" w ramach konferencji naukowej. 
Źródłem dumy jest także z reguły dynamika w postępowaniu wychowanka, która jest interpretowana przez personel jako poprawa, dająca nadzieję na resocjalizację. Przykładem takiej poprawy jest podejmowana przez wychowanka próba włączania wychowawcy w jego prywatne życie.

Ostatnio zostałem pozytywnie zaskoczony gdy jeden z trudniejszych wychowanków gdzie dzwoniono przed jego przybyciem z ostrzeżeniem, że jest trudny i ciężki, że jest nastawiony na szantaż i trzy dni temu zaprosił mnie do znajomych na Facebooku, ale jest to krok w dobrą stronę [wychowawca, SdN].

\section{Pozytywne emocje personelu w relacjach z wychowankami a więź emocjonalna}

Emocja dumy często przeradza się w więź emocjonalną, której z reguły wychowankowie są bardzo spragnieni. Więź emocjonalna ma istotny wpływ na skuteczność procesu resocjalizacyjnego, a nawet go warunkuje.

[Wychowankowie] potrzebują nieraz takiego poklepania ojcowskiego na zasadzie pomocy, wsparcia i wtedy jeżeli widzą, że ten człowiek nie że się z nich naśmiewa, tylko im pomaga... Śmieszna sytuacja à propos takiej właśnie rzeczy, uczenia ich - pokazałem im jak zawiązać krawat, no i oni patrzą w tą telewizję tam wszyscy prawie w tych krawatach i jak ich zapytałem o te krawaty wcześniej przed zajęciami, o te koszule a tam Panie, co to tam....bzdury jakieś, ale jak wyprasowali sobie sami te koszule, sami zawiązali ten krawat, wszyscy kazali sobie robić zdjęcia i mało tego, te zdjęcia wysyłali w listach do mamy, do domu, pisząc na odwrocie: zobacz jak ładnie wygladam i takie rzeczy, nie? Czyli z jednej strony gdzieś tam $\mathrm{z}$ kapturem stoją gdzieś tam $\mathrm{w}$ tych bramach, a $\mathrm{z}$ drugiej strony potrzebują takich rzeczy. [...] ja też mam syna w wieku 9 lat i powiem szczerze, że sam wewnętrznie nie raz mam do siebie pretensje, że więcej jakby chcę przekazać tym chłopakom, niż swojemu dziecku. W wypadku swojego dziecka wiem, że ma ten dom normalny, że ta rodzina jest w miarę normalna, że wszystko jest OK [wychowawca, ZP].

Więź emocjonalna przekłada się na zaangażowanie ze strony pracowników, które jest odwzajemniane przez wychowanków. Nabierają oni przekonania, że wychowawcy „robią coś ponadprogramowego” dla nich, co wzmaga poczucie lojalności i bliskości. W takim kontekście przekazywane przez personel treści częściej są przez podopiecznych inkorporowane i internalizowane.

To znaczy oni mają bardzo dużą potrzebę uwagi, bardzo potrzebują zainteresowania, bardzo potrzebują takiej autentycznej relacji, [...] nawet jak im się coś mówi, że coś źle zrobili....ale żeby oni widzieli zaangażowanie tego pracownika pedagogicznego prawda, jak to się ładnie określa, żeby widzieli zaangażowanie w to, co się z nim dzieje. Jak oni widzą taką bliższą więź, że temu czy wychowawcy, czy psychologowi, czy pedagogowi zależy na tym, co się $\mathrm{z}$ nim dzieje, no to jest ta praca z wychowankiem [psycholog, SdN]. 
My chłopaków niejednokrotnie zabieraliśmy do domu, żeby im pokazać jak wyglądają święta. Pewnie, że człowiek ryzykuje ale chce się, żeby choć raz zobaczyli jak może być normalnie [wychowawca, ZPiSdN].

Więź emocjonalna i bliska relacja $\mathrm{z}$ niej wynikająca niekiedy nie mają odzwierciedlenia we wzorach ich przyjmowania przez podopiecznych, którzy nigdy nie doświadczyli bliskości, nie potrafią jej przyjmować i interpretować. W tym aspekcie można mówić nie o resocjalizacji, lecz o socjalizacji pierwotnej, w której wypracowywane są wzory interakcyjne ze znaczącymi innymi [Cooley 1909: 23; Sullivan 1953: 8].

Miałem taką sytuację, przychodzi do mnie chłopak i mówi, że nauczyciel zawodu go przytulił. Ja już mam w głowie całą tragedię, że wykorzystał seksualnie, że pedofil a chłopak ze łzami w oczach mówi, że nikt go nigdy w życiu jeszcze nie przytulił, nie pokazał uczucia, że to jego pierwszy raz kiedy ktoś mu pokazał uczucie i bliskość [wychowawca, SdN].

\section{SPOSOBY RADZENIA SOBIE Z EMOCJAMI NEGATYWNYMI}

W tej części artykułu omówione są różne uwarunkowania leżące u podstaw podjęcia pracy emocjonalnej, zarówno w wymiarze płytkim, jak i głębokim.

\section{Pozytywne emocje jako motywatory do podejmowania strategii radzenia sobie $z$ emocjami negatywnymi w ramach pracy emocjonalnej}

Z prowadzonych przeze mnie obserwacji wynika, że pozytywne emocje spełniają niejako rolę ,generatorów energii” w momentach, gdy nie czerpie się jej bezpośrednio z pracy. Zgromadzone dane potwierdzają także wnioski, do których dochodzą Min Joo Kim i Sun Young Han $^{8}$ [2009: 227], że ekspresja pozytywnych emocji przekłada się na pozytywne emocjonalne doświadczanie pracy i większą pewność w relacjach międzyludzkich. Personel dość często odwołuje się do pozytywnych emocji w chwilach zmęczenia i braku motywacji, wspominając z detalami przykłady udanych działań resocjalizacyjnych.

Jak dla nich, to jest mega, oni tego nie mają i dlatego człowiek gdzieś tam tak się angażuje w tą pracę, że po pewnym czasie robią się takie trochę relacje ojcowskie, natomiast oni nigdy nie podziękują za to... 99\% nie podziękuje, jeden tam może podziękuje za to, że ktoś się tak zaangażował i pomógł [wychowawca, ZP].

8 Autorzy zaznaczają [2009: 229-230] także, że praca emocjonalna w pewnych przypadkach może prowadzić do nadmiernego stosowania używek, stresu, separacji od przeżywanych emocji, spadku satysfakcji z pracy etc. Dzieje się tak wtedy, gdy pracownik w ramach płytkiej pracy emocjonalnej jest zmuszony udawać emocje, których faktycznie nie przeżywa. 
Ja uwielbiam tę pracę i chyba bym nie mogłabym wykonywać innej. Wiadomo, że czasami jest ciężko, dziewczyny są niewdzięczne, ale gdy widzisz jak choć niektóre z nich wychodzą na prosta, to od razu ci się chce, widzisz sens swojej pracy i to jest super [nauczycielka, ZP].

Wnioskuję, że emocje częściowo spełniają rolę weryfikatora przydatności do zawodu. Dla osób, które odnajdują się w pracy resocjalizacyjnej, pozytywne doznania stanowią nie tylko wsparcie w chwilach kryzysu, ale i utwierdzają je w przekonaniu, że robią właściwe rzeczy, zgodne ze swoimi poglądami i koncepcją siebie. Pozostałe osoby zdecydowanie rzadziej doznają emocji pozytywnych. Rzeczywistość instytucyjna postrzegana jest przez nich w kategoriach trudności, niewygody, stresu, dyskomfortu. Niekiedy jest to konsekwencją mylnych założeń i wyobrażeń przed przystąpieniem do pracy.

Musisz mieć to coś, to może być twoja pasja, hobby nieważne, coś czymś zainteresujesz chłopaków. Mieliśmy tu jednego wojskowego, który wydawało się, że będzie pasował jak ulał, nie dał rady już po paru tygodniach, sam zrezygnował [kierownik internatu, ZP].

Do pewnego stopnia można założyć, że to wychowankowie po części decydują o tym, kto będzie z nimi pracował, a kto nie. Emocje doznawane przez nich, a także odczuwane przez personel tworzą pewien wzór interakcyjny, który jest dość czytelny dla całej społeczności zakładowej. Stygmat „złego wychowawcy” noszą ci, którzy nie doświadczają i nie kreują pozytywnych emocji wokół siebie $\mathrm{i}$ innych.

\section{Świadomość własnych emocji a praca emocjonalna}

U podstaw pracy emocjonalnej leży wypracowanie mechanizmów zwiększających samoświadomość [Shott 1979] w zakresie kontekstów występowania emocji, zwłaszcza tych negatywnych. Praca na rzecz świadomości obejmuje zdobywanie wiedzy na temat swoich dyspozycji do reagowania w określonych okolicznościach, które prowadzą do występowania reakcji emocjonalnych. Pierwszym etapem jest praca emocjonalna płytka, wyrażająca się $w$ dostosowaniu do okoliczności zewnętrznych oznak emocji negatywnych [Hochschild 2009: 42]. Oznacza to, że personel nadal przeżywa emocje negatywne (złość, nienawiść, wstręt itd.), lecz na skutek pracy nad sobą i dostosowania warstwy behawioralnej do okoliczności dostosowuje się wtórnie [Goffman 2011: 182] do kontekstu instytucjonalnego i interakcyjnego. Z obserwacji i wypowiedzi wychowanków wynika, że rozpoznają oni pracę płytką personelu, gdyż dostrzegają nieszczerość, brak spójności pomiędzy okazywanymi na zewnątrz i faktycznie odczuwanymi emocjami. W przypadku pracy głębokiej dostrzegają oni autentyczność, czyli spójność fasady [Goffman 2000: 57]. 
Ludzie połykają te emocje inkorporują je - odczuwają i puszczają dalej - racjonalizujesz je sobie, mówisz sobie ze to nie jest jego wina, myśląc o jego przestępstwie myślisz sobie o podstawach, starasz się oddzielić od chłopca. Wspólne spędzanie czasu. Wychodzi się z roboty gdy czujesz że wybuchniesz żeby przemyśleć i nie wchodzisz w interakcje. Jak ci grozi lepiej się odwrócić na pięcie i odejść ale nie pokazać emocji strachu, gniewu czy zainteresowania, Staram się opanować gniew - liczę do 10 żeby nie wybuchnąć. Np. metoda gdy cię obraża to nie może cię obrażać bo jesteś starszy, mądrzejszy, sprytniejszy itd. [wychowawca, SdN].

W ramach procesów uświadamiających własne emocje istotne jest rozpoznanie własnych skłonności, które przekładają się na błędy w ocenie. Dopuszczenie do siebie świadomości pomyłki i jej konsekwencji stanowi ważny element pracy nad sobą i własnymi emocjami.

Też jesteśmy ludźmi tylko i sam się przyznaję, że parę razy pewnie też gdzieś tam nieuczciwie podszedłem do tematu na zasadzie takiej, że tego nie lubię za bardzo, więc... a jeszcze go na czymś złapałem, to mu jeszcze większą karę wymyśliłem, temu, którego lubiłem to machnąłem ręką dobra tam ostatni raz. Pracujemy właśnie z żywymi ludźmi jakby i to się gra na emocjach i odwrotnie: mamy takie momenty, do domu wracam, że spokojnie mógłbym usiąść przed telewizorem oglądać [...] a mam nie raz tak, że przychodzę do domu pół nocy nie mogę zasnąć, bo myślę, analizuję coś tam i się zastanawiam jak to rozgryźć później czy dobrze, czy źle, albo wręcz wyrzuty sumienia [wychowawca, ZP].

Praca nad emocjami może także występować w przypadku emocji pozytywnych, kiedy ekspresja stoi w sprzeczności z celami pedagogicznymi. Można zatem mówić także o powstrzymywaniu emocji pozytywnych, gdy wymaga tego określony kontekst sytuacyjny.

Miałem takiego wychowanka który zajmował się komputerami i chciałem się od niego dowiedzieć czegoś, ale nie mogłem mu pokazać zainteresowania tym jak się włamywał, bo to by było niepedagogiczne. Przyjeżdża chłopak super zbudowany jak go zapytać żeby nie pokazać zainteresowania, bo może brał jakieś anaboliki, bo jak to będzie wyglądało? [wychowawca, $\mathrm{SdN}]$.

W przypadku personelu, który nie pracuje nad świadomością własnych emocji negatywnych i strategiami zapanowania nad nimi, uwalniają się one w sposób niekontrolowany, prowadząc do działań destruktywnych zarówno wobec podopiecznych, jak i samego siebie. Zdarza się, że personel prowokuje różne sytuacje, by na zasadzie samospełniającego się proroctwa [Zimbardo 1999: 606-607] udowodnić słuszność swojej definicji danego podopiecznego.

Najgorzej nie lubię w zakładach tego, że jak coś się zrobi źle u wychowawcy, to on później się mści przez jakiś czas. Tam jeszcze jest w szkole taka wychowawczyni... ja miałem straszny problem z nią i ciagle miała do mnie jakiś problem i ja po prostu w ogóle nie komentowałem nic, nie chciałem z nią w ogóle mieć do czynienia, w końcu jej coś odpowiedziałem, ona nakręciła wychowawców z grup, że ja jej tak odpowiadam i później wychowawcy mieli do 
mnie problem. Mnie wkurzają tacy wychowawcy, którzy się mszczą. Czasem też prowokują. Ogólnie wszędzie, jest z wychowawców strony prowokacja czasem [wychowanek, ZP].

Personel, zwłaszcza ten z krótkim stażem, niejako testuje na sobie określone strategie służące opanowaniu emocji negatywnych. Wśród nich można wymienić:

- mentalne przenoszenie się do innego kontekstu sytuacyjnego (np. myślenie o znajomych, rodzinie, rzeczach materialnych);

- skupianie się na innej czynności, która nie jest związana z doświadczaną sytuacją stresogenną (np. odliczanie);

- dowartościowywanie własnego ja poprzez porównywanie siebie do wychowanka, który jest przyczyną emocji negatywnych i umniejszanie jego wpływu na własną osobę (np. myślenie o jego niedostatkach intelektualnych, fizycznych);

- przypominanie sobie sytuacji dostarczających emocji pozytywnych w przeszłości (np. sięganie pamięcią do sukcesów pedagogicznych).

Przejście od płytkiej do głębokiej pracy emocjonalnej wiąże się z takim oddziaływaniem wobec swojej jaźni, którego konsekwencją jest faktyczna zmiana stanu emocjonalnego z negatywnego na pozytywny. Zmiana ma charakter jakościowy i wiąże się z transformacją emocji negatywnych w pozytywne. U jej źródeł leży wypracowanie technik obronnych własnego ja i przyswojenie indywidualnego wypracowywanego interakcyjnie wzoru wzbudzania w sobie emocji pozytywnych [por. Hochschild 2009: 42].

Jeżeli czuję że nie nadaję z kimś na tych samych falach to zastanawiam się czy to moje decyzje, zachowania to staram się to w sobie znaleźć i zmienić ale też patrzę czy ten powód jest tylko u mnie. Mam dość dużą tolerancję i przymykam oczy na negatywne zachowania innych ludzi - wyczekuję, nie działam nerwowo. Jeśli jest to kwestia drugiej strony to staram się dociec do źródeł jak się nie uda to zostawiam bo wiem że się nie uda i lepiej się wycofać [wychowawca, SdN].

Ważnym mechanizmem, niejako „pośredniczącym” pomiędzy pracą płytką i głęboka, w przypadku personelu jest swego rodzaju „,internalizacja” mentalnej koncepcji braku wdzięczności i odseparowanie jej od działań wzbudzających emocje pozytywne. Wychowawcy oczekujący wdzięczności w przypadku jej braku przeżywają frustrację, kierując ją na wychowanków. Żeby uchronić dotychczasowe przekonanie o sobie, racjonalizują brak wdzięczności roszczeniowością wychowanków i ich niską społecznie użytecznością. Ci wychowawcy, którzy przechodzą nad tym do porządku dziennego, próbują zrozumieć brak wdzięczności, nie obwiniając o to wychowanków, lecz warunki środowiska, w którym żyli. W obydwu przypadkach dochodzi do podtrzymania własnego ja, choć jedynie w drugiej sytuacji można mówić o pracy głębokiej. 
[...] wiele zależy od grupy wychowanków, poczucie niewdzięczności i roszczeniowość mniej doświadczeni liczą na wdzięczność a doświadczeni nauczyli sobie z tym radzić. Wiele zależy od tego jak się wchodzi do pracy, lubią coś robić ale oczekują ciągle wdzięczności, im więcej zrobią tym bardziej liczą na wdzięczność i dowartościowanie ze strony dyrektora lub/i wychowanków - łatwiej o rozczarowanie w pracy. Uczelnia - wykładowcy mówią, że wystarczy dać serce a młodzi się odwdzięcza - nikt nie lubi być długo wdzięcznym (wychowankowie). Dylemat my - oni: ci co tak mówią uważają ze wystarczy im zaoferować cokolwiek i będą wdzięczni. Mają mało więc jeśli dostają za darmo to powinni być wdzięczni [wychowawca, ZP].

W procesie przechodzenia od pracy emocjonalnej płytkiej do głębokiej ważna jest nie tylko wspomniana wcześniej świadomość własnych emocji, lecz także emocji wychowanków oraz kontekstu ich występowania. Jest to o tyle istotne, że choć ekspresja emocjonalna może wyglądać tak samo (np. okazywanie złości poprzez agresję werbalną), to jej pochodzenie może być różne od pierwotnie zakładanego. W przypadku pracy płytkiej stłumieniu podlega samo okazanie emocji negatywnych, natomiast w przypadku pracy głębokiej nie dochodzą one do skutku w konsekwencji działań ukierunkowanych na próbę zrozumienia uwarunkowań kontekstualnych warunkujących określone intencje i interakcje z nimi związane. Świadomość intencji podopiecznego ma wpływ na sposób jego odbioru i emocje temu towarzyszące.

R: [...] on miał naprawdę dziury w mózgu, bo on nie wiedział o czym mówi czasami, nie wiedział co my do niego mówimy. Ja prowadziłem z nimi zajęcia jakieś tam o filmie czy o teatrze i on odezwał się, że tam jakiś film widział i że tam w tym filmie to coś fajnego było i tak naprawdę powiedział to co chciałem usłyszeć - pochwaliłem go, powiedziałem super stary faktycznie tak bylo jak ty mówisz jest OK i od tego momentu on tego nie zrozumiał, on myślał, że ja mu ubliżam i zaczęła się jakaś taka pyskówka, wiadomo, że ja sobie na to nie pozwoliłem, więc go wyprowadziłem z tych zajęć, bo w sumie nie wiedziałem, o co mu chodzi, skąd ta agresja nagle się w nim wzięła, czy to dlatego, że go pochwaliłem? Okazało się, że on tego nie zrozumiał, mało tego wszedłem za nim do sypialni, bo on się później już nakręcił, a on wziął kubek, zbił ten kubek i stanął przede mną na zasadzie takiej, że jak podejdę, to on mi da tym kubkiem. Wtedy zastosować można środek przymusu bezpośredniego, ja mówię stuchaj ty ważysz $50 \mathrm{~kg}$, ja ważę 110, dwa metry miedzy nami, jak podejdę do ciebie i będziesz nadal z tym kubkiem stat, to będzie środek przymusu bezpośredniego i użyję sity fizycznej, odpuść sobie, bo mnie po prostu nie zrozumiateś prawdopodobnie i on sobie odpuścił nie.... Wyszło OK nie zrozumiał o co mi chodziło i ja mu to potem wytłumaczyłem, ale on był tak długo męczony przez nich tam psychicznie, że gdzieś nie wytrzymał i już [wychowawca, ZP].

Pogłębiona refleksja nad intencjami wychowanka pozwala zrozumieć kontekst interakcyjny ich występowania. Zdarza się, że w pewnych okolicznościach podopieczny może być częściowo „rozgrzeszony” ze swoich działań, co niejako automatycznie stawia go w innym świetle i pociaga za sobą inne emocje ze strony 
opiekuna. Z reguły ci wychowawcy, którzy podejmują pogłębioną analizę sytuacji, zdecydowanie lepiej radzą sobie z własnymi emocjami, wykonują skuteczną głęboką pracę emocjonalna, a także odczuwają większą satysfakcję z jej efektów. $\mathrm{W}$ rezultacie budują oni głębsze więzi emocjonalne $\mathrm{z}$ wychowankami i osiaggaja dzięki temu lepsze efekty resocjalizacyjne.

No ale on [wychowanek] i tak musi pamiętać, że jest w tej grupie i tamci mu nie każą na przykład czegoś robić, to on nie będzie robił, będzie czasami mi się przeciwstawiał, tylko dlatego, że jakiś silniejszy mu kazał, bo on jest za słaby, żeby się postawić. I często działają pod wpływem swoich kolegów. To jest taka właśnie ta największa trudność, najtrudniej się nauczyć, zdobyć taką umiejętność, żeby ocenić daną sytuację, teraz trzeba umieć to rozdzielić, która sytuacja była prawdziwa, a która jest dlatego, że musi [wychowawca, ZP].

Mimo pozornej indywidualizacji rzadko kiedy pojawia się refleksja na temat [wychowanka] sytuacji rodzinnej, osobowości, ludzie szukają problemów gdzie indziej lokując ją w wychowanku a nie patrząc na kontekst [dyrektor szkoły, ZP].

\section{Przejście od płytkiej do głębokiej pracy emocjonalnej uprawdopodabnia szansę na większą skuteczność oddziaływań resocjalizacyjnych}

Uzupełnieniem, a jednocześnie konsekwencją poprzedniej hipotezy jest hipoteza mówiąca o ścisłym związku zmiany jakościowej, zachodzącej pomiędzy przejściem z pracy emocjonalnej na poziomie płytkim do tej na poziomie głębokim, ze skutecznością oddziaływań resocjalizacyjnych. Całość procesu transformacji odbywa się przy znacznym udziale samoświadomości emocjonalnej, opisywanej wcześniej. Świadomość wraz z przekonaniem o skuteczności strategii emocjonalnych nakierowanych na faktyczne przeżywanie pozytywnych emocji i szukania sposobów ich ekspresji warunkuje skuteczność przekazu.

Staramy się mieć emocje pozytywne a ukrywać negatywne emocje. Był wychowanek co powiedział parę słów za dużo, ale zastanawiasz się dlaczego tak się zachowuje i co ci da jego demolowanie. Ważna jest świadomość siebie i negatywnych emocji, jeśli wiesz że na ciebie źle oddziałuje to już możesz z tym cos zrobić. Najgorzej gdy nie jesteś tego świadomy [wychowawca, ZP].

Skuteczna praca emocjonalna na poziomie głębokim opiera się także na „odpowiedniości" pomiędzy wypracowanymi strategiami wzbudzania w sobie emocji pozytywnych i faktycznego ich przeżywania a ich ekspresją. Relewancja pomiędzy emocją a jej ekspresją może być interpretowana w kategoriach wspomnianej Goffmanowskiej spójności fasady i poddawana krytyce w momencie, gdy budzi wątpliwości [Kim, Han 2009: 229]. O takiej osobie mówi się, że gra lub nie jest naturalna, co podlega ocenie podopiecznych i ma wpływ na jej wiarygodność. 
Natomiast w grupie tworzą bardzo dobrych obserwatorów, bardzo dobrze rozszyfrowują każdego pracownika. No to jest taka siła tej grupy, dlatego jeżeli będą udawać, jeżeli pracownik będzie coś udawał, no to to wypłynie wcześniej czy później, bo pracujemy tu dosyć długo, wiele tych godzin jest i nie da się tak, jeżeli mamy jakieś tam słabości, z którymi sobie nie radzimy, to oni to wyczują wcześniej czy później [wychowawca, ZP].

Wysoka świadomość własnych emocji w ramach głębokiej pracy emocjonalnej pozwala nawet na sprawne oddzielenie faktycznie przeżywanych emocji od ich ekspresji przy jednoczesnym utrzymaniu spójności fasady. Wprawa w instrumentalnym eksponowaniu emocji pozwala uczynić z nich narzędzie wpływu [Cialdini 2009] i wykorzystywać je do kreowania sytuacji interakcyjnej zgodnie $\mathrm{z}$ aktualnymi potrzebami.

Nasza praca opiera się na graniu na emocjach wychowanków i swoich własnych. Staram się żeby emocje były pozytywne, jeśli jesteś nastawiony pozytywnie to możesz tym grać: jestem nastawiony pozytywnie a ty mnie tak traktujesz. Może się jednak zdarzyć że on tego nie odwzajemnia [dyrektor szkoły, ZP].

Praca emocjonalna na poziomie głębokim i związana z nią wysoka świadomość własnych emocji i sposobów ich ujawniania wydaje się kompetencją stałą, gdyż nabyta pozwala wychowawcy na efektywną pracę z „trudnymi” podopiecznymi, także tymi, co do których nie istnieje uzasadnione przekonanie o możliwości poprawy z racji ich uwarunkowań mentalnych. Mowa tutaj o wychowankach szczególnego rodzaju, mianowicie tych o skłonnościach socjo- i psychopatycznych. Psychologowie i psychiatrzy z działu diagnostycznego/diagnostyczno-korekcyjnego są zgodni, że w przypadku tej kategorii podopiecznych już na wstępie nie można oczekiwać pełnych efektów, czyli skutecznej resocjalizacji. Relacja z młodocianymi o tego rodzaju skłonnościach wymaga ab ovo przyjęcia pewnych założeń przy aktywizacji pozytywnych emocji okazywanych w kontakcie z nimi. Praca taka wymaga doświadczenia i dużej świadomości.

B: A jak pracujecie np. z psychopatami lub socjopatami?

R: Ja uważam, żeby starać się, żeby różne te socjopatyczne zachowania one tu nie wybuchły, bo to jest kwestia czasu, kiedy on to zrobi i pociagnie innych za sobą, ja akurat tego chłopaczka, bo właśnie wiem o kim mówisz, wdrożyłem w drużynę szpiku', biegał z nami w różnych zawodach. I uważam, że to bardzo fajnie się u niego sprawdzało i to hamowało jego prawdziwe oblicze. Jak mówię, moja obserwacja, trzeba było w niego uwierzyć, ale to jest socjopata i naprawdę do końca nie było wiadomo kiedy wybuchnie, aczkolwiek to był

9 W jednym z zakładów poprawczych uruchomiono program „Drużyna Szpiku”, by zachęcać wychowanków do brania udziału w przeszczepach szpiku kostnego dla ratowania życia potrzebujących. 
chłopaczek bardzo inteligentny, naprawdę miał jakiś zasób wiedzy, potrafił też dobrze manipulować i zabłysnąć swoją wiedzą, mimo swego młodego wieku. A wiadomo, jest to bardzo ciężka praca z takimi osobami, które mają takie skłonności, no ale było trzeba pracować, ale no jest to jakby usypianie jego tych skłonności natury, do tego, żeby było dobrze, żeby dobrze funkcjonował [wychowawca, ZP].

W tym miejscu należy zaznaczyć, że z racji tego, iż samo pojęcie pracy emocjonalnej, w tym płytkiej i głębokiej, jest pewnym konceptem teoretycznym, trudno precyzyjnie wydzielić zestaw kryteriów, które pozwalają ponad wszelką wątpliwość stwierdzić fakt takiej transformacji [Hochshild 2009]. Koncepcja pracy emocjonalnej stymuluje do prowadzenia badań w tym kierunku oraz ma wartość poznawczą. Trzeba jednak pamiętać, że sama koncepcja wymaga jeszcze dopracowania i dalszej konceptualizacji.

\section{PODSUMOWANIE I ZAKOŃCZENIE}

W artykule poruszony został problem zarówno doświadczania emocji, jak i ich ekspresji w przypadku pracowników instytucji korekcyjnych. Choć treść niniejszej pracy w żadnym wypadku nie wyczerpuje tego problemu - który jest o wiele bardziej złożony - to jednak zgromadzony przez siedem lat badań materiał empiryczny pozwala stwierdzić pewne zależności i tendencje oraz ostrożnie odnieść się do przyjętych hipotez.

Przede wszystkim można mówić o bardzo ważnej roli emocjonalności w procesach i działaniach związanych z pracą resocjalizacyjną. Emocje mogą decydować o skuteczności oddziaływań, ich zahamowaniu, a nawet wywołaniu skutków przeciwnych. W przypadku występowania emocji negatywnych powstałych u pracowników na skutek ich kontaktów z podopiecznymi niezwykle istotną rolę należy przypisać samoświadomości stanowiącej klucz do podjęcia działań mających w zamyśle kontrolę ekspresji emocjonalnej. Kontrola tego rodzaju pozwala uczynić z emocji, zarówno tych pozytywnych, jak i negatywnych, swoiste „narzędzie” wywierania wpływu. Dochodzi zatem do instrumentalnego i intencjonalnego oddzielenia faktycznie przeżywanych emocji od korespondującej z nimi warstwy behawioralnej. Samoświadomość to także podstawa do przejścia od płytkiej pracy emocjonalnej do głębokiej, które wiąże się z transformacją emocji negatywnych w pozytywne. Praca głęboka przekłada się na motywację do działania i budowania pozytywnej atmosfery, której konsekwencją jest proces tworzenia więzi emocjonalnej z podopiecznymi. To z kolei wzmaga indywidualizację relacji wychowawca-wychowanek, a także ją pogłębia, stwarzając możliwość większej skuteczności przekazywa- 
nia treści prospołecznych. Uzyskane wyniki potwierdzają zatem przyjętą tezę o kluczowym znaczeniu emocji w procesie instytucjonalnego oddziaływania resocjalizacyjnego.

\section{BIBLIOGRAFIA}

Blumer Herbert. 1969. Symbolic interactionism. Perspective and method. Englewood, New Jersey: Prentice-Hall.

Brook Paul, Gertraud Koch, Andreas Wittel. 2013. "Thirty years after Hochschild's 'Managed Heart': Exploring the commodity frontier”. Culture and Organization 19(4): 275-282.

Cialdini Robert. 2009. Wywieranie wptywu na ludzi. thum. B. Wojciszke. Gdańsk: GWP.

Chomczyński Piotr. 2013. „Problem bezpieczeństwa personelu zakładów poprawczych dla nieletnich w kontaktach z wychowankami. Socjologiczna analiza czynników wewnętrznych". Profilaktyka Społeczna i Resocjalizacja 21: 91-117.

Collins Randall. 2004. Interaction, ritual chains. New Jersey: Princeton University Press.

Collins Randall. 1993. "Emotional energy as the common denominator of rational action". Rationality and Society 5, (2 April): 203-230.

Cooley Charles H. 1909. Social organization: A study of the larger mind. New York: Charles Scribner's Sons.

Cooley Charles H. 1922. Human nature and the social order (revised edition). New York: Charles Scribner's Sons.

Czyżewski Marek. 2013. „Socjologia interpretatywna i metoda biograficzna: przemiana funkcji, antyesencjalistyczne wątpliwości oraz sprawa krytyki”. Przegląd Socjologii Jakościowej IX(4): 14-27.

Denzin Norman K. 1983. "A note on emotionality, self, and interaction”. American Journal of Sociology 89(2) (September): 402-409.

Doliński Dariusz 2004. Mechanizmy wzbudzania emocji. W: Psychologia. Podręcznik akademicki. Tom 2, Psychologia ogólna. J . Strelau (red.), 319-350. Gdańsk: Gdańskie Wydawnictwo Psychologiczne.

Durkheim Émile. 1990, Elementarne formy życia religijnego. System totemiczny w Australii. tłum. A. Zadrożyńska. Warszawa: Wydawnictwo Naukowe PWN.

Elias Norbert. 2011. O procesie cywilizacji. tłum. T. Zabłudowski i K. Markiewicz. Warszawa: Wyd. W.A.B.

Fehr Beverley, James A. Russel. 1984. "Concept of emotion viewed from a prototype perspective". Journal of Experimental Psychology, General 113: 464-486.

Fagerhaugh Shizuko, Anselm Strauss. 1977. Politics of pain management. Menlo Park, California. Addison\&Wesley.

Goffman Erving. 1961. Asylums: Essays on the social situation of mental patients and other inmates. New York, Doubleday; wersja polska: 2011. Instytucje totalne. O pacjentach szpitali psychiatrycznych i mieszkańcach innych instytucji totalnych. tłum. O. Waśkiewicz i J. Łaszcz. Sopot: GWP.

Goffman Erving. 2000. Człowiek $w$ teatrze życia codziennego. thum. H. Datner-Śsiewak, P. Śpiewak. Warszawa: Wyd. KR. 
Goffman Erving. 2008. Embarrassment and social organization. W: Emotions. A social science, M. Greco, P. Stenner (eds.), 106-111. London-New York: Routledge, Taylor \& Francis.

Hammersley Martyn, Paul Atkinson. 2000. Metody badań terenowych. thum. S. Dymczyk, Poznań: Wyd. Zysk i S-ka.

Hochschild Arlie R. 1979. "Emotion work, feeling rules, and social structure". American Journal of Sociology 85(3 Nov.): 551-575.

Hochschild Arlie R. 1983. The managed heart: Commercialization of human feeling. Berkeley: University of California Press.

Hochschild Arlie R. 2009. Zarządzanie emocjami. Komercjalizacja ludzkich uczuć. Warszawa: Wydawnictwo Naukowe PWN.

Kemper Theodore D. 1987. "How many emotions are there? Wedding the social and autonomic components". American Journal of Sociology 93: 263-289.

Kemper Theodore D. 2011. Status, power and ritual interaction. A relational reading of Durkheim, Goffman and Collins. Surrey, Great Britain: Ashgate Publishing Limited.

Kerr Mary, Elizabeth L. Brown. 2016. "Preventing school failure for teachers, revisited: Special educators explore their emotional labor". Preventing School Failure: Alternative Education for Children and Youth 60(2): 143-151.

Kim Min J., Suk Y. Han. 2009. "Relationship between emotional labor consequences and employees' coping strategy". Asia Pacific Journal of Tourism Research 14(3): 225-239.

Kofta Mirosław. 1979. Samokontrola a emocje. Warszawa: Wydawnictwo Naukowe PWN.

Konecki Krzysztof T. 2000. Studia z metodologii badań jakościowych: teoria ugruntowana. Warszawa: Wydawnictwo Naukowe PWN.

Konecki Krzysztof T. 2005. Ludzie $i$ ich zwierzęta. Interakcjonistyczno-symboliczna analiza społecznego świata właścicieli zwierzą domowych. Warszawa: Wyd. Naukowe SCHOLAR.

Moczydłowski Pawel. 2002. Drugie życie więzienia. Warszawa: Oficyna Wydawnicza Łośgraf.

Mucha Janusz. 1992. Cooley. Warszawa: Wyd. Wiedza Powszechna.

Pawłowska Beata, Piotr Chomczyński. 2012. „The methods of negative emotions managing based on teachers' control group research", Culture and Education 6(92): 212-235.

Pawłowska Beata. 2013. Emocje społeczne w pracy nauczyciela i przedstawiciela handlowego. Łódź: Wyd. Uniwersytetu Łódzkiego.

Piotrowski Andrzej. 1985. „Osobowość a tożsamość. O pewnej tendencji we współczesnej socjologii interakcji”. Folia Sociologica 12: 19-44.

Plutchik Robert. 1980. Emotion: A psychoevolutionary synthesis. New York: Harper \& Row.

Price Heather. 2001. "Emotional labour in the classroom: A psychoanalytic perspective". Journal of Social Work Practice 15(2): 161-180.

Reykowski Janusz. 1992. Emocje, motywacja, osobowość. Warszawa: Wydawnictwo Naukowe PWN.

Scheff Thomas M., Suzanne M. Retzinger. 1997. "Shame, anger and the social bond: A theory of sexual offenders and treatement". Electronic Journal of Sociology Sept. http://www. sociology.org.

Scheff Thomas M. 2003. Goffman's elaboration of the looking glass self, referat wygłoszony podczas dorocznego zjazdu Amerykańskiego Stowarzyszenia Socjologicznego (American Sociological Association) Atlanta, [online] http://www.soc.ucsb.edu/faculty/scheff/19a.pdf.

Scheff Thomas M. 2006. "Concepts and concept formation: Goffman and Beyond". Qualitative Sociology Review II(3): 48-64. 
Shaver Phillip, Judith Schwartz, Donald Kirson, Cary O'Connor. 1987. "Emotion knowledge. Further exploration of a prototype approach". Journal of Personality and Social Psychology 52: 1061-1086.

Simmel Georg. 1955. Conflict and the web of group afiliations. thum. R. Bendix. Glencoe: Free Press.

Strauss Anselm, Shizuko Fagerhaugh, Barbara Suczek, Carolyn Wiener. 1982. "Sentimental work in the technologized hospital”. Sociology of Health and Illness 4(3): 254-278.

Sullivan Harry S. 1953. The interpersonal theory of psychiatry. New York: W.W. Norton \& Company.

Szczygieł Dorota, Róża Bazińska, Roma Kadzikowska-Wrzosek, Sylwiusz Retowski. 2009. „Praca emocjonalna w zawodach usługowych - pojęcie, przegląd teorii i badań”, Psychologia Społeczna 4, 3(11): 155-166.

Turner Jonathan H. 2004. Struktura teorii socjologicznej. thum. G. Woroniecka, J. Szmatka, A. Manterys, A. Mościskier, K. Wysieńska, E. Zakrzewska-Manterys, M. Bucholc, Z. Karpiński. Warszawa: Wydawnictwo Naukowe PWN.

Turner Jonathan H., Jan E. Stets. 2009. Socjologia emocji. thum. M. Bucholc. Warszawa: Wydawnictwo Naukowe PWN.

Zapf Dieter. 2002. "Emotion work and psychological well-being. A review of the literature and some conceptual considerations". Human Resource Management Review 12: 237-268.

Zimbardo Philip. 1999. Psychologia i życie. tłum. E. Czerniawska, J. Łuczyński, J. Radzicki, J. Suchecki. Warszawa: Wydawnictwo Naukowe PWN.

Piotr Chomczyński

\title{
EMOTIONS AND EMOTIONAL WORK IN SOCIAL REHABILITATION PROCESSES AMONG STAFF IN JUVENILE CORRECTIONAL INSTITUTIONS
}

\begin{abstract}
This article depicts the problem of both the arousal of emotions and emotional work, both of which occur among the personnel of juvenile detention centers and juveniles' shelters, in the context of the effectiveness of social rehabilitation. The article employs the concept of emotional work to describe and explain pedagogical actions initiated in correctional institutions. It adopts the thesis that the key condition of effective social rehabilitation is emotional work, which is undertaken by personnel in their daily relations with inmates. As they experience negative emotions, the personnel have to construct their own ways of dealing with them. The article also covers the concept of personnel's surface and deep emotional work - both of which affect their interactions with juveniles.

The results presented in this paper are based on an eight-year qualitative study carried out in all types of juvenile correctional institutions across Poland. The study used the triangulation principle gathering methods, researcher and data. To analyze empirical data the interpretative paradigm was employed, which makes it possible to examine the arousal of emotions and the initiation of emotional work.
\end{abstract}

Keywords: emotional work, juvenile correctional institutions, total institutions, interpretative paradigm, interactions, social rehabilitation 